\title{
Population size structure and abnormalities in the number of rays of the Sea Star Pentaceraster cumingi (Valvatida: Oreasteridae) in Bahía Chamela, Mexican Pacific
}

Cristian Moisés Galván-Villa ${ }^{1 *} \&$ Francisco Alonso Solís-Marín ${ }^{2}$

1. Laboratorio de Ecosistemas Marinos y Acuicultura, Departamento de Ecología Aplicada, Centro Universitario de Ciencias Biológicas y Agropecuarias, Universidad de Guadalajara, Camino Ramón Padilla Sánchez No. 2100, Nextipac, Zapopan, Jalisco, México. C.P. 45200; cristian.galvan@academicos.udg.mx

2. Colección Nacional de Equinodermos "Dra Ma. Elena Caso Muñoz", Laboratorio de Sistemática y Ecología de Equinodermos, Instituto de Ciencias del Mar y Limnología (ICML), Universidad Nacional Autónoma de México, Av. Ciudad Universitaria 3000, Coyoacán, Ciudad de México, México. C.P. 04510; fasolis@cmarl.unam.mx * Correspondence

Received 28-VII-2020. Corrected 20-XI-2020. Accepted 27-XI-2020.

\begin{abstract}
Introduction: The Panamic Cushion Star Pentaceraster cumingi is widely distributed along the Tropical Eastern Pacific. This species strictly produces only five arms, but sometimes, this number varies or show another kind of abnormality. Objective: We aimed to evaluate the population size structure and abnormalities occurrence in the radial pattern of $P$. cumingi in Bahía Chamela, Jalisco, Mexico. Methods: The population was monitored along four years (2016-2019), in two seasonal periods (warm and cold). During fieldwork, a random sample of individuals was collected. Every starfish was measured, weighted, and evaluated to identify any abnormality on its radial pattern. Results: The highest density of $P$. cumingi was found in October 2019 $\left(2.03 \pm 0.05 \mathrm{ind} / \mathrm{m}^{-2}\right)$, the lower in March $2017\left(0.66 \pm 0.13 \mathrm{ind} / \mathrm{m}^{-2}\right)$. A total of 849 individuals were collected. For 5-armed starfishes, the average length was $123.8 \pm 15.2 \mathrm{~mm}$ and the average weight of $326.0 \pm 62.4 \mathrm{~g}$. The most frequent length classes ranged from 110 to $120 \mathrm{~mm}$. Of the total of individuals sampled $0.82 \%$ had four arms, $1.06 \%$ six, and $1.41 \%$ had one bifurcated arm. Conclusions: There were differences in the population density and size structure of $P$. cumingi between seasons. The main causes of abnormalities in the starfish could be due to the changes that occur during larval metamorphosis or by an abnormal regeneration of the arms after a predation attempt.
\end{abstract}

Key words: Sea star; abnormality; density; echinoderm; structure size; Tropical Eastern Pacific.

Galván-Villa, C.M., \& Solís-Marín, F.A. (2021). Population size structure and abnormalities in the number of rays of the Sea Star Pentaceraster cumingi (Valvatida: Oreasteridae) in Bahía Chamela, Mexican Pacific. Revista de Biología Tropical, 69(1), 262-273. DOI 10.15517/rbt.v69i1.43239

Echinoderms are an ancient lineage of invertebrates that exhibit primitive characters like autotomy, regeneration, radial symmetry, and asexual reproduction (James, 1999). The asteroids (sea stars or starfishes) are present in many different marine environments, from deep abyssal depths to the intertidal zone, from the tropics to the poles (Mah \& Blake, 2012; O’Hara \& Byrne, 2017; Diupotex-Chong,
Solís-Marín, \& Laguarda-Figueras, 2017). Although asteroids are not typically abundant in marine ecosystems, they influence biodiversity, population dynamics, and can exert control on community structure as predators in intertidal and subtidal ecosystems (Lawrence, 2013; Menge \& Sanford, 2013).

Starfish exhibit usually a pentameral symmetry, although numerous-armed starfish have 
between six to 40 rays (Hotchkiss, 2000a), e.g., Heliaster helianthus (Lamarck, 1816), Pycnopodia helianthoides (Brandt, 1835), Acanthaster planci (Linnaeus, 1758). Starfish rays exhibit a great variety of functions like locomotion (Migita, Mizukamib, \& Gunji, 2005; Lawrence, 2013), to force open the shells of mollusks (Lavoie, 1956), parental care (Chia, 1966; Hamel \& Mercier, 1995), food detection (Lawrence, 1987; Moore \& Lepper, 1997; Dale, 1999), to right themselves (Migita et al., 2005), respiration (Lawrence, 2013), to adhere to the seabed when buffeted by waves (Thomas \& Hermans, 1985; Santos, Gorb, Jamar, \& Flammang, 2005), and to flee under emergency conditions (Emson \& Wilkie, 1980).

Regeneration is a common phenomenon in all actual echinoderm classes (Yousra et al., 2018; Byrne, 2020). It has been particularly well-studied in asteroids, where three main aspects have been identified: 1) regeneration of body parts (arms) following self-induced or traumatic amputation; 2) regeneration of internal organs (pyloric caeca and cardiac stomach) following self-induced or traumatic mutilation, and 3) fission processes (Candia-Carnevali, 2006). Regeneration of body parts and environmental perturbations on the metamorphosis of larvae can result in an abnormality in the number of starfish arms (Hotchkiss, 1979).

Worldwide the largest record of occurrences of abnormal starfishes have been reported in India, where at least 13 species have been listed: Anthenea pentagonula (Lamarck, 1816) (Maheswaran, Narendran, Yosuva \& Gunalan, 2015), Asterina lorioli Koehler, 1910 (James, 1999), Astropecten indicus Döderlein, 1888 (James, 1999; Prabhu \& Bragadeeswaran, 2012; Chamundeeswari, Saranya, Shanker, Varadharajan, \& Rajagopal, 2013), A. karankawai Lawrence, Cobb, Herrera, Durán-González \& Solís-Marín, 2018 (ICMYL Unpublished data), Echinaster purpureus (Gray, 1840) (James, 1999), Goniodiscaster vallei (Koehler, 1910) (Maheswaran et al., 2015), Linckia laevigata (Linnaeus, 1758) (James, 1999), L. multifora (Lamarck, 1816) (James, 1999; Maheswaran et al., 2015), L. columbiae Gray, 1840 (Fisher, 1945), Nardoa galatheae (Lütken, 1864) (James, 1999), Pentaceraster regulus (Müller \& Troschel, 1842) (James, 1999; Shanker \& Vijayanand, 2014), Pisaster ochraceus (Brandt, 1835) (Fisher, 1945), and Protoreaster linckii (Blainville, 1830) (James, 1999; Chelladurai, Balakrishnan, Jayanthi, Ajeesh-Kumar, \& Mohanraj, 2015; Chelladurai \& Doss, 2016). Other species where abnormal ray numbers have been recorded include Protoreaster nodosus (Linnaeus, 1758), a starfish widely distributed in the Indo-Pacific region (Chim \& Tan, 2012) and Archaster angulatus Müller \& Troschel, 1842 from the Indian Ocean and western Pacific (Keesing, 2017).

The Panamic Cushion Star Pentaceraster cumingi (Gray, 1840) (Asteroidea: Oreasteridae) is one of the most common starfish in the Tropical Eastern Pacific (TEP) (SolísMarín et al., 2014; Reyes-Bonilla, VázquezArce, González-Cuéllar, Herrero-Pérezrul, \& Weaver, 2016). It has a highly variable coloration, from red-orange or red-green to a gray background color with an overlying bright red network (Kerstitch \& Bertsch, 2007). P. cumingi, like most starfish, has pentameric symmetry, is relatively large (up to $17.4 \mathrm{~cm}$ of diameter), with an inflated body wall, and immobile spines stud in the upper surface. It is distributed from the Gulf of California, Mexico to Northern Perú, inhabits rocky reefs, patch reefs, and sandy areas, from low intertidal zone up to 183 m deep (Hickman, 1998; Solís-Marín et al., 2014).

The Mexica buried echinoderms in their ritual deposits for at least a half-century. Six species of starfish have been found so far in the offerings, and the presence of $P$. cumingi was common (10000 elements have been found in 13 offerings) (Martín-Cao-Romero et al., 2017). While it is true that many animals (or artifacts made from them) were buried as gifts to the supernatural, in most cases they were manipulated as symbols of specific divinities, of particular regions of the universe, or of important cosmic processes (López-Luján, 
Chávez-Valderas, Zúñiga-Arellano, AguirreMolina, \& Valentín-Maldonado, 2012).

It is well known that this starfish forms large aggregations, which may correspond to feeding (Reyes-Bonilla, González-Azcárraga, \& Rojas-Sierra, 2005) or a reproductive strategy (Reyes-Bonilla et al., 2016). The Panamic Cushion Starfish plays an important ecological role, maintaining the benthic communities in the TEP by feeding on microorganisms and other echinoderms, such as sea urchins, controlling populations of those species (Dee, Witman, \& Brandt, 2012; Reyes-Bonilla et al., 2016). The present study focuses on the population density, size structure, and occurrence of abnormalities in the radial pattern of an established population of $P$. cumingi from the central Mexican Pacific.

\section{MATERIALS AND METHODS}

The study was carried out in front of El Novillo islet in Bahía Chamela, Jalisco, in the Central Mexican Pacific (19'33'15' N \& 10507'25” W). The Bahía Chamela was declared a Natural Protected Area in 2002, with the Sanctuary category. Includes seven main islands (Pajarera, Cocinas, La Colorada, San Agustín, San Pedro, San Andrés, and La Negra) and some islets. El Novillo islet (also called Islote Novillos) is rocky with a maximum elevation of $13 \mathrm{~m}$, its surface of $0.73 \mathrm{ha}$, and its located $1400 \mathrm{~m}$ from mainland. Around the islet, the habitat consists of a sandy plain and mixed rubble substrate, with maximum depths of 7-10 m (Ríos-Jara et al., 2013). Organisms were sampled from June 2016 to October 2019 (cold and warm seasons). One sampling event was conducted at each season for every year. To determine the density of starfishes in the area, three belt transects of 20x1 m were made, per sampling campaign, by SCUBA diving. Transects were placed parallel to each other and separated two meters between them. A total of 849 starfishes were collected randomly. The measurements that were took were arm length (A, B, C, D, and E) from the mouth center to the tip of arm, minor radius length $(r)$ from mouth center to the end of interradius (C-D), arm breadth $(b r)$ at the base of the A-arm (in the case no A-arm, it was replaced with the B-arm), the number of arms, and weight (using a portable electronic balance, $1 \mathrm{~g}$ accuracy). All specimens were drained on a plastic tray before recording the weight, to eliminated variability on weighing. Arms position was determined following the Carpenter system, which recognized the C- and D-arm where the madreporite exists in-between, and the opposite arm to madreporite as A-arm (Hotchkiss, 2000a). Starfishes with an abnormal number of arms were photographed in oral and aboral views, to determine the presence and direction of the ambulacral grooves. After being measured and photographed, all individuals were returned to the sea. Water temperature and maximum depth were recorded with a diving computer (Dive Rite Nitek duo). To calculate radius length-weight relationships, pentameric specimens were selected. Abnormal starfishes were examined independently. All data was analyzed using the Minitab 17 software.

\section{RESULTS}

Population size structure: For analysis of population size structure, only five armed starfishes were considered. The density of P. cumingi in El Novillo islet exhibited little variation throughout the sampling period (Kruskal-Wallis test $\mathrm{H}=9.14, \mathrm{P}=0.243$ ). The highest mean density was found in October $2019\left(2.03 \pm 0.05 \mathrm{ind} / \mathrm{m}^{-2}\right)$ and the lowest in March $2017\left(0.66 \pm 0.13 \mathrm{ind} / \mathrm{m}^{-2}\right)$. Mean density for the other months ranged from 1.34 to $1.91 \mathrm{ind} / \mathrm{m}^{-2}$ (Fig. 1). In general, the highest densities were found during the warm season, although no relationship was observed between abundance and temperature. Cold season temperature values ranged from 20.6 to $27.9{ }^{\circ} \mathrm{C}$ and warm season ranged from 29.0 to $30.5^{\circ} \mathrm{C}$. Average major radius $(R)$, minor radius $(r)$, and arm breadth $(b r)$ were similar between the sampling months, except for $b r$ in October 2016 which was the lowest of all (Table 1). 


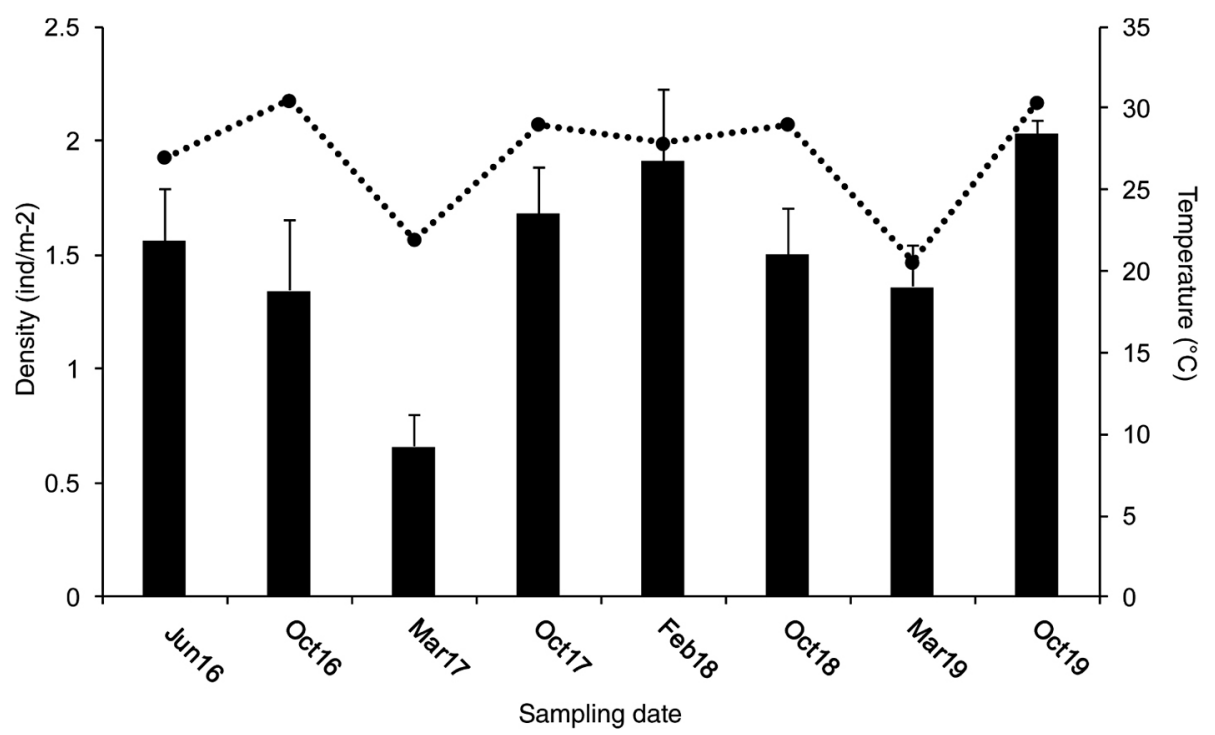

Fig. 1. Density of individuals (bars) and water temperature (dotted line) records by sampling date.

TABLE 1

Abundance and growth rates of Pentaceraster cumingi by sampling date

\begin{tabular}{lccccccc} 
Sampling date & $\begin{array}{c}\text { Number of } \\
\text { starfish in } \\
\text { sample }\end{array}$ & $\begin{array}{c}\text { Number of } \\
\text { abnormal } \\
\text { starfish* }\end{array}$ & $\begin{array}{c}\text { Mean R } \\
(\mathrm{mm})\end{array}$ & Mean r (mm) & Mean br $(\mathrm{mm})$ & Depth $(\mathrm{m})$ & Temp $\left({ }^{\circ} \mathrm{C}\right)$ \\
Jun. 2016 & 94 & 0 & $112.1 \pm 11.2$ & $56.0 \pm 5.6$ & - & 9.3 & 27.0 \\
Oct. 2016 & 148 & 10 & $112.8 \pm 13.7$ & $52.4 \pm 6.3$ & $38.6 \pm 14.7$ & 7.2 & 30.5 \\
Mar. 2017 & 81 & 2 & $114.8 \pm 8.7$ & $50.2 \pm 5.6$ & $52.4 \pm 8.6$ & 7.2 & 21.9 \\
Oct. 2017 & 119 & 2 & $113.6 \pm 12.4$ & $46.9 \pm 6.1$ & $59.2 \pm 9.7$ & 7.6 & 29.0 \\
Feb. 2018 & 115 & 7 & $114.0 \pm 14.1$ & $46.8 \pm 6.1$ & $55.2 \pm 10.9$ & 6.5 & 27.9 \\
Oct. 2018 & 90 & 0 & $114.9 \pm 10.8$ & $45.9 \pm 5.2$ & $53.9 \pm 7.2$ & 7.7 & 29.0 \\
Mar. 2019 & 80 & 1 & $113.5 \pm 11.1$ & $47.4 \pm 5.6$ & $58.8 \pm 13.2$ & 7.2 & 20.6 \\
Oct. 2019 & 122 & 6 & $123.0 \pm 13.0$ & $50.0 \pm 7.0$ & $58.0 \pm 9.0$ & 7.3 & 30.4 \\
Total & 849 & 28 & & & & & \\
\hline
\end{tabular}

Arm breadth for June 2016 were not measured. *excluded from the mean values.

The maximum size $(R)$ of collected starfish was $160 \mathrm{~mm}$. The average length for normal starfish was $123.8 \pm 15.2 \mathrm{~mm}$ and the average weight was $326.0 \pm 62.4 \mathrm{~g}$ (Table 2). The most frequent length classes ranged from 110 to 120 $\mathrm{mm}$ (Fig. 2). Larger individuals $(>150 \mathrm{~mm}$ ) were found in October 2019 and small individuals $(<50 \mathrm{~mm})$ were found in October 2016, 2017 and February 2018. The length classes were widely separated in October 2016 than the other months. Differences in the arm length $(\mathrm{t}=-3.95 ; \mathrm{P}<0.05)$ and body weight $(\mathrm{t}=2.82$; $\mathrm{P}=0.005)$ were found between cold and warm seasons (Fig. 3).

Occurrence of abnormal starfish. A total of 849 individuals of $P$. cumingi were collected and measured, 28 of them (3.29\%) had an abnormal arm number (i.e. individuals with four arms, six arms, and with a bifurcated arm, Table 1). From all samples, $0.82 \%$ had four arms, $1.06 \%$ had six arms, and $1.41 \%$ had one 

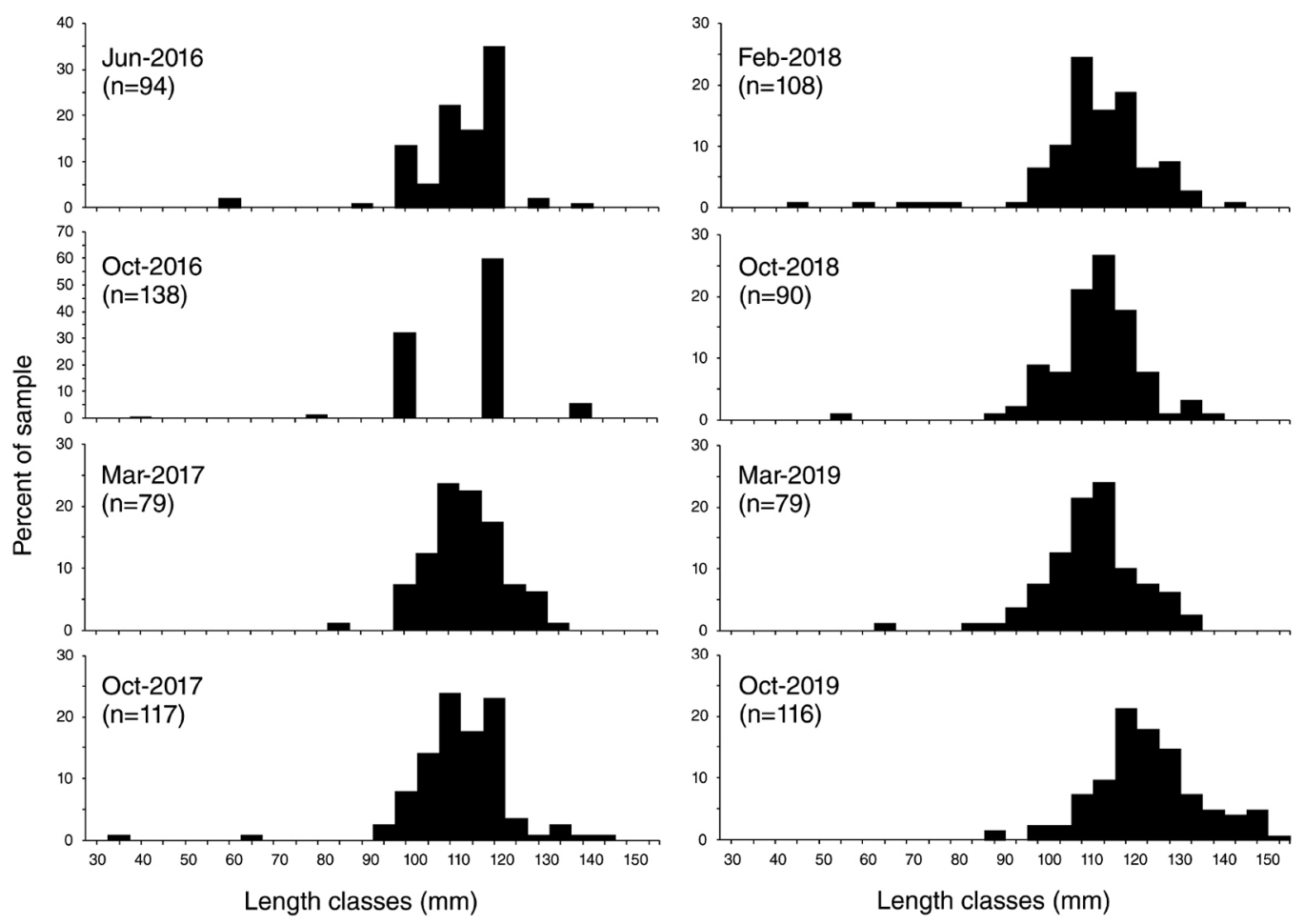

Fig. 2. Size-frequency distributions of Pentaceraster cumingi from Bahía Chamela, Mexico.

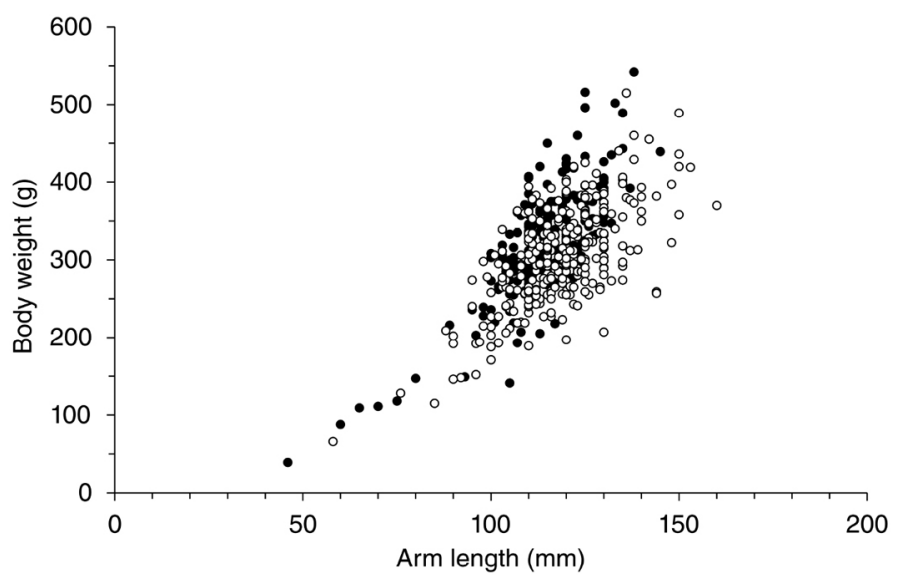

Fig. 3. Length-weight relationships of Pentaceraster cumingi in cold (black circles) and warm (white circles) seasons.

bifurcated arm. The largest number of abnormal starfish was found in October 2016 when the individual size was the lowest, followed by February 2017 and October 2019.

Abnormalities in $P$. cumingi radial pattern are caused at least by three processes: 1) by mutilation of one arm, which gives rise to a four-armed starfish (Fig. 4b). In this case, an external mechanism, such as predation, causes the abnormality, and because a remnant of the lost arm is present there is a possibility for regeneration; 2) malformations during 


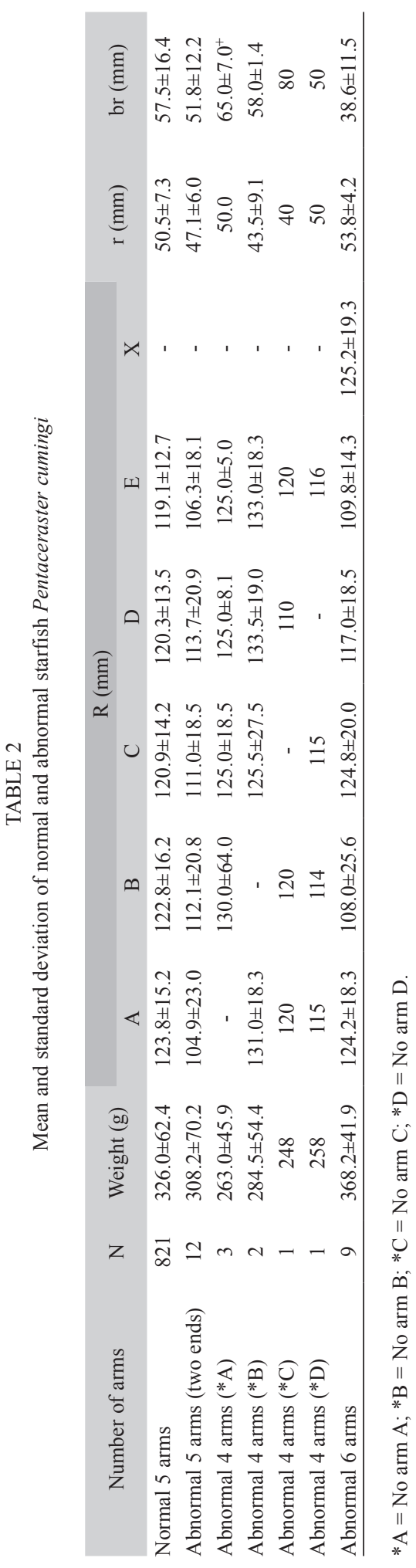

development, can give rise to four or six armed starfish (Fig. 4c, Fig. 4e), one individual presented a fusion of two ambulacral grooves (Fig. 4d); and 3) by regeneration, can give rise to a bifurcated arm (Fig. 4f). Bifurcated arms were found only in five-armed starfish and no more than one bifurcated arm was found in the same individual.

\section{DISCUSSION}

The species richness of Asteroidea in Bahía Chamela is low. Only three species have been recorded in the bay: Phataria unifascialis (Gray, 1840), Pharia pyramidata (Gray, 1840), and P. cumingi (Ríos-Jara et al., 2013). The low species richness maybe related to a poor sampling effort on starfishes itself. Taking into consideration that some starfish have specific habits, like being nocturnal, roost under rocks, inside cavities, or are buried in soft bottoms, therefore their record can be hard or less detectable with common methods. However, these three species are dominant because they can colonize easy different types of habitats (Luna-Salguero \& Reyes-Bonilla, 2010). The occurrence of $P$. cumingi at Bahía Chamela is continuous throughout the year, with densities that are constant in both seasons (cold and warm). The species reaches population densities from $0.8 \mathrm{ind} / 50 \mathrm{~m}^{2}$ in the Gulf of California, Mexico (Reyes-Bonilla et al., 2005) to $0.02 \mathrm{ind} / \mathrm{m}^{2}$ in the Gulf of Chiriqui, Panama (Alvarado, Guzmán, \& Breedy, 2012). Starfish densities in Bahía Chamela ranged from 0.66 to $2.03 \mathrm{ind} / \mathrm{m}^{2}$, above of those reported for other sites. Population density is similar to those found in aggregation events (probably for a reproduction event) in the Southern Gulf of California, where densities of up to $3 \mathrm{ind} / \mathrm{m}^{2}$ were reported (Reyes-Bonilla et al., 2016). However, these aggregations have been observed only for a few days, unlike the population at Bahía Chamela, which is constant all year. Physical and environmental conditions in the bay such as shallow water, weak currents that provide protection of islands and islets, warmer temperatures, and extensive sandy 


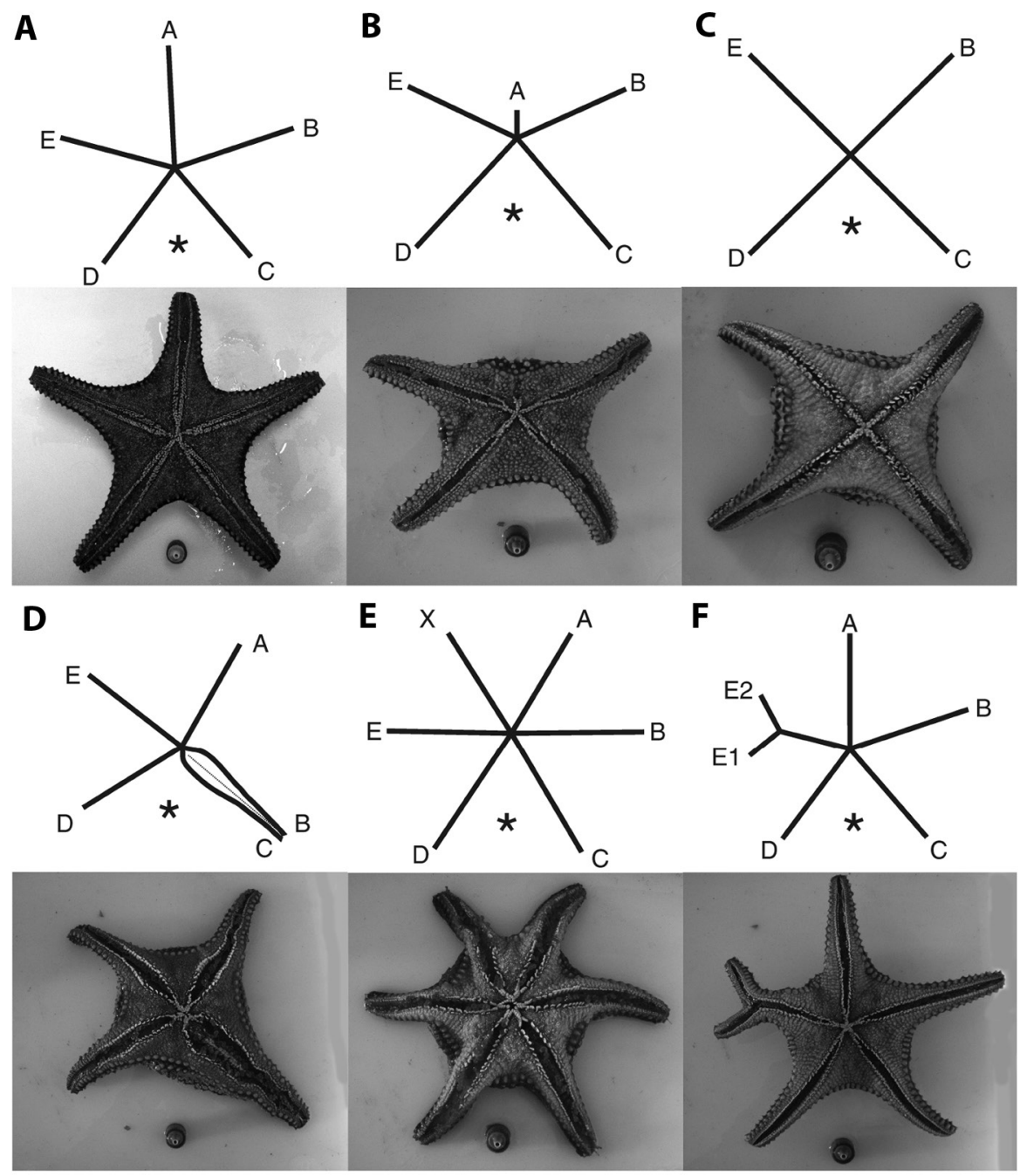

Fig. 4. Position and sequence of ambulacral grooves abnormalities in Pentaceraster cumingi in oral view. A. Five rays. B-D. Four rays. E. Six rays. F. Five rays with one bifurcation. * Represents madreporite position.

bottoms can provide sufficient resources (space and food) to maintain a persistent aggregation of P. cumingi (Sloan \& Aldridge, 1981; Guillou, 1996; Reyes-Bonilla et al., 2005).

Due to the lack of studies of $P$. cuming $i$ populations in other localities, it is not possible to compare the mean population sizes present in Bahía Chamela. The P. cumingi population exhibited a seasonal growth pattern, with differences between cold and warm seasons. A possible explanation for this difference is that the length-weight relationship between seasons varied according to factors such a food availability, feeding rate, gonad development, and spawning period (Sebens, 1987). The growth rate for $P$. cumingi seems to be related to seawater temperature as higher growth rates were recorded in the months when seawater temperature was also higher. Seasonal variation in growth had been described for other starfish 
species, which usually showed a decrease in growth rate associated with gonad maturation (Freeman, Richardson, \& Seed, 2001).

Recruitment events are thought to have occurred between June and August (summer), however, recruits of $P$. cumingi occur in cryptic habits and their observation is hard. One recruit $(<10 \mathrm{~mm})$ was found attached under a rock in a rocky reef habitat, away from the area where adults were found (Galván-Villa pers. obser.). Possibly, juveniles (> $30 \mathrm{~mm}$ ) may migrate from rocky reefs to rubble areas, where adults feed to continue its growth. Spatial patterns in the recruitment of starfishes have been associated with different habitat characteristics such as depth, substrate type, temperature, and hydrodynamics (Metaxas, 2013). This selection of habitat has been associated with increased survival, which in turn is affected by the availability of food and predation pressure (Johnson, Sutton, Olson, \& Giddins, 1991; Manzur, Barahona, \& Navarrete, 2010).

Pentaceraster cumingi belongs to the family Oreasteridae, which is one of the twenty living families of starfishes that are exclusively five-rayed (Hotchkiss, 2000a). Arm number abnormalities are relatively common in the family Oreasteridae. Other studies have reported similar conditions for the congener $P$. regulus, a common starfish from the Western Central Pacific (James, 1999; Shanker \& Vijayanand, 2014), P. linckii, widely distributed in the Indian Ocean (James, 1999; Chelladurai et al., 2015; Chelladurai \& Doss, 2016), and $P$. nodosus, from the Indo-Pacific region (Chim $\&$ Tan, 2012). Abnormal arm number have been attributed to several causes like injury, regeneration errors, malnutrition, congenital issues, or damages in the metamorphosis process (Moore, 1974; Hotchkiss, 1979; Watts, Scheibling, Marsh, \& McClintock, 1983). The most common cause seems to be by regeneration process (Hotchkiss, 1979). Incidence of mutilation in some starfish has been suggested by fishing gears (Ramsay et al., 2001; Byrne, 2020). It is not considered in this study because the population studied was located inside a protected area where fishing activities are not allowed.

Some lab experiments have shown that changes in environmental factors like salinity can influence ray formation during early development in asteroids (Watts, Scheibling, Marsh, \& McClintock, 1982; Marsh, Watts, Chen, \& McClintock, 1986; Clark, 1988). Watts et al. (1983) reported a rise of metamorphosed individuals with ray number abnormalities by increasing salinity to $39 \%$. The incidence of arm abnormalities in $P$. cumingi from Bahía Chamela was higher in comparison with another species studied. For the starfish Archaster angulatus Müller \& Troschel, 1842, Lawrence, Keesing and Irvine (2010), found an incidence of $0.4 \%$ of both four and six arm abnormalities, and Keesing (2017) found an incidence of $1.5 \%$ of four arms and $1.3 \%$ of six arms in the same species. It is not possible to determine the causes of this high level of arm abnormality in $P$. cumingi, due to the lack of more environmental data. Other factors, such as sample method, size distribution area, and habitat type should be considered for estimation of the incidence of abnormalities.

Four arm condition is not common in starfishes. Some specimens with four evident arms, but with five ambulacral grooves, were found in Bahía Chamela. In these cases, injury or arm mutilation for depredation is the cause of the apparent abnormality, but the arm can be regenerated, as it was observed in other specimens. On the other hand, specimens with four arms and four ambulacral grooves support the synchronic hypothesis, in which abnormalities arise during the metamorphosis, when the pathway to form the rudiments of the five primary rays operates for only a short time, switches off and does not re-occur (Hotchkiss, 2000a). As mentioned above, changes in environmental parameters may be the cause of this abnormality.

Only one specimen with a double ambulacral groove was found. This abnormality is very rare, and it has been reported in a few other sea stars as Asterias forbesi (Desor, 1848), A. problema Lutken, 1872, A. rubens Linnaeus, 1758, 
Eremicaster vicinus Ludwing, 1907, Pisaster ochraceous segnis Fisher, 1926, and Stephanasterias albula (Stimpson, 1853) (Hotchkiss, $2000 \mathrm{~b}$ ) and it is considered a result of injury or a regeneration process. Hotchkiss (2000b) deduced that this abnormality is a rare result of regeneration, in which the two terminal plates remain coalesced along their inner margin, the ambulacral grooves are kept parallel, and there is just one tip to the double ray. However, in the specimen found in Bahía Chamela, the two ambulacral grooves were fused at the base, and most of this abnormality likely arose during metamorphosis, and not by a regeneration process. A detailed examination of terminal plates, adambulacral, inferomarginal and superomarginal plates is necessary to establish the origin of the abnormality. Other conditions there will develop two tips to the ray but no individuals with this characteristic were found.

Due to the basic skeletal structure of asteroids with flexible arms, they have both species and genera with pentameral and other symmetries (Stephenson, 1967). The supernumerary rays of multiradiate species as Acanthaster, Pycnopodia, Solaster, Crossaster, etc., was explained by the 'Five-Plus' hypothesis, that proposes that supernumerary rays develop by independent pathways that operate after the five primary rays have initially formed (Hotchkiss, 2000a). For pentamerous species, the apparition of an extra ray is an unusual event that has not been well studied. The six-armed abnormality was the most common (1.06 \%) in $P$. cumingi. Examination of the ventral view of specimens allowed to confirm the presence of six ambulacral grooves and to separate from specimens with a bifurcation caused by an injury. The presence of well-defined six ambulacral grooves could demonstrate that the abnormality is the result of the metamorphosis process, altered maybe for environmental changes (e.g. Marsh et al., 1986).

The presence of morphological abnormalities is less favorable to survival of individuals, and the incidence of abnormalities can be an indicator of environmental degradation (Jangoux, 1987). Wu, Ji, Wang, and Lv (2012) used mathematical and physical methods to evaluate the superiority of starfish with five arms in comparison with those with a different number of arms, concerning detection, turning over, autotomy, and adherence. They conclude that the optimal number of arms varies under different environmental conditions. In the case of multiradiate taxa some advantages have been identified. Supernumerary rays increase the number of tube feet, then multiradiate asteroids could be more mobile, more resistant to being detached from the seabed, and more successful feeders (Herringshaw, Smith, \& Thomas, 2007). Although four-armed starfish exhibited such disadvantages that it is hard for them to survive, the relatively smaller disadvantages of six-armed starfish might allow a few species to exist but the advantages of five arms will permit it to evolve into the dominant pattern of species. As other authors suggest, further studies are needed to understand the causes for the abnormality in pentameral starfishes and the mechanisms that cause it.

Ethical statement: authors declare that they all agree with this publication and made significant contributions; that there is no conflict of interest of any kind; and that we followed all pertinent ethical and legal procedures and requirements. All financial sources are fully and clearly stated in the acknowledgements section. A signed document has been filed in the journal archives.

\section{ACKNOWLEDGMENTS}

Thanks to all students of the "Recursos Marinos" course who contributed with the fieldwork. To Manuel Ayón and Cande Hernández for field support in Chamela for many years. To Kevin Cummings for the English writing and grammar revision. Special thanks to the Biology Station of Chamela (IBUNAM) for all facilities during field sampling. This research was supported partially by P3E program from the University of Guadalajara. Field collection of specimens was done with the official permission of SEMARNAT 
(SGPA/DGVS/05775/12). The authors would like to thank anonymous reviewers for substantial comments that contribute to the final version of this manuscript.

\section{RESUMEN}

Estructura de tallas poblacional y anormalidades en el número de radios de la estrella de mar Pentaceraster cumingi (Valvatida: Oreasteridae) en Bahía Chamela, Pacífico mexicano. Introducción: La Estrella Cojín Pentaceraster cumingi está ampliamente distribuida a lo largo del Pacífico Oriental Tropical. Esta especie produce estrictamente cinco brazos, pero en algunas ocasiones el número puede ser menor o mayor de cinco, o mostrar otro tipo de anormalidad. Objetivo: Evaluar la estructura de tallas poblacional y la presencia de anormalidades en el patrón radial de $P$. cumingi en la Bahía Chamela, Jalisco, México. Métodos: La población fue monitoreada a lo largo de cuatro años (2016-2019), durante dos periodos estacionales (cálido y templado). Durante el trabajo de campo se recolectó una muestra aleatoria de individuos. Cada estrella de mar fue medida, pesada y revisada para identificar alguna anormalidad en el patrón radial. Resultados: La mayor densidad de individuos se encontró en octubre de 2019 $\left(2.03 \pm 0.05 \mathrm{ind} / \mathrm{m}^{-2}\right)$, la menor en marzo de $2017(0.66 \pm$ $0.13 \mathrm{ind} / \mathrm{m}^{-2}$ ). Un total de 849 individuos fueron recolectados. Para las estrellas de mar con 5 brazos, la longitud promedio fue de $123.8 \pm 15.2 \mathrm{~mm}$ y el peso promedio de $326.0 \pm 62.4 \mathrm{~g}$. La clase de talla más frecuente varió entre 110 y $120 \mathrm{~mm}$. Del total de individuos muestreados el 0.82 $\%$ tuvieron cuatro brazos, el $1.06 \%$ con seis, y el $1.41 \%$ tuvieron un brazo bifurcado. Conclusiones: Se encontraron diferencias en la densidad poblacional y en la estructura de tallas de $P$. cumingi entre estaciones. Las principales causas de anormalidades en la estrella de mar pueden ser debidas a los cambios que ocurren durante la metamorfosis de las larvas o por una regeneración anormal de los brazos a causa de la depredación.

Palabras clave: estrella de mar; anormalidad; densidad; equinodermo; estructura de tallas; Pacífico Oriental Tropical.

\section{REFERENCES}

Alvarado, J.J., Guzmán, H.M., \& Breedy, O. (2012). Distribution and diversity of echinoderms (Asteroidea, Echinoidea, Holothuroidea) in the islands of the Gulf of Chiriqui, Panama. Revista de Biología Marina y Oceanografia, 47, 13-22.

Byrne, M. (2020). The Link between Autotomy and CNS Regeneration: Echinoderms as Non-Model Species for Regenerative Biology. BioEssays, 42(3), 1900219.
Candia-Carnevali, M.D. (2006). Regeneration in Echinoderms: repair, regrowth, cloning. Invertebrate Survival Journal, 3, 64-76.

Chamundeeswari, K., Saranya, S., Shanker, S., Varadharajan, D., \& Rajagopal, S. (2013). New occurrence of abnormal sea star, Astropecten indicus from Mudasalodai, south east coast of India. Cell \& Developmental Biology, 2(2), 1000116.

Chelladurai, G., Balakrishnan, S., Jayanthi, G., AjeeshKumar, K.K., \& Mohanraj, J. (2015). Report on the occurrence of abnormal four-armed red-knobbed starfish Protoreaster linckii (Echinodermata: Astroidea), Tuticorin coast, south-east coast of India. Marine Biodiversity Records, 8, 1-4.

Chelladurai, G., \& Doss, A. (2016). Peculiar star fish Protoreaster linckii (Echinodermata: Astroidea) from Tuticorin coastal water, Gulf of Mannar. Oceanography \& Fisheries, 1(2), 555559. DOI: 10.19080/ OFOAJ.2016.01.555559

Chia, F.S. (1966). Brooding behavior of a six-rayed starfish, Leptasterias hexactis. Biological Bulletin, 130, 304-315.

Chim, C.K., \& Tan, K.S. (2012). Recognition of individual knobby sea stars Protoreaster nodosus (L., 1758) using aboral Surface characteristics. Journal of Experimental Marine Biology and Ecology, 430, 48-55.

Clark, K.E. (1988). The roles of heredity, osmotic stress, and regeneration in non-pentamerous symmetry in Patiria miniata (Asteroidea). In R.D. Burke, P.V. Mladenov, P. Lambert, \& R.L. Parsley (Eds.), Echinoderm Biology (pp. 792-792). Neatherlands, Rotterdam: Balkema.

Dale, J. (1999). Coordination of chemosensory orientation in the starfish Asterias forbesi. Marine and Freshwater Behaviour and Physiology, 32, 57-71.

Dee, L.E., Witman, J.D., \& Brandt, M. (2012). Refugia and top-down control of the pencil urchin Eucidaris galapagensis in the Galápagos Marine Reserve. Journal of Experimental Marine Biology and Ecology, 416, 135-143.

Diupotex-Chong, M.E., Solís-Marín, F.A., \& LaguardaFigueras, A. (2017). Evidencia de la existencia de ojos compuestos (omatidias) en la estrella de mar Pentaceraster cumingi (Gray, 1840). Jaina Boletín Informativo, 28(1), 11-15.

Emson, R.H., \& Wilkie, I.C. (1980). Fission and autotomy in echinoderms. Oceanography and Marine Biology: An Annual Review, 18, 155-250.

Fisher, W.K. (1945). Unusual abnormalities in sea-stars. Journal of the Washington Academy of Sciences, 35(9), 296-298. 
Freeman, S.M., Richardson, C.A., \& Seed, R. (2001). Seasonal abundance, spatial distribution, spawning and growth of Astropecten irregularis (Echinodermata: Asteroidea). Estuarine and Coastal Marine Science, $53,39-49$.

Guillou, M. (1996). Biotic and abiotic interactions controlling starfish outbreaks in the Bay of Douarnenez, Brittany, France. Oceanologica Acta, 19(3-4), 415-420.

Hamel, J.F., \& Mercier, A. (1995). Prespawning behavior, spawning, and development of the brooding starfish Leptasterias polaris. Biological Bulletin, 188, 32-45.

Herringshaw, L.G., Smith, M.P., \& Thomas, A.T. (2007). Evolutionary and ecological significance of Lepidaster grayi, the earliest multiradiate starfish. Zoological Journal of the Linnean Society, 150, 743-754.

Hickman, C.P. Jr. (1998). A field guide to sea stars and other Echinoderms of Galápagos. Lexington, Virginia: Sugar Spring Press.

Hotchkiss, F.H.C. (1979). Case studies in the teratology of starfish. Proceedings of the Academy of Natural Science of Philadelphia, 131, 139-157.

Hotchkiss, F.H.C. (2000a). On the number of rays in starfish. American Zoologist, 40, 340-354.

Hotchkiss, F.H.C. (2000b). Inferring the developmental basis of the sea star abnormality "double ambulacral groove" (Echinodermata: Asteroidea). Revista Chilena de Historia Natural, 73, 579-483.

James, D.B. (1999). Abnormal asteroids from the seas around India. Marine Fisheries Information Service: Technical and Extension Series, 159, 21-22.

Jangoux, M. (1987). Diseases of Echinodermata. IV. Structural abnormalities and general considerations on biotic diseases. Diseases of Aquatic Organisms, $3,221-229$.

Johnson, C.R., Sutton, D.C., Olson, R.R., \& Giddins, R. (1991). Settlement of crown-of-thorns starfish: role of bacteria on surfaces of coralline algae and a hypothesis for deepwater recruitment. Marine Ecology Progress Series, 71, 143-162.

Keesing, J.K. (2017). Population size structure, growth, arm number and damage in the sea star Archaster angulatus Müller and Troschel, 1842 (Echinodermata: Asteroidea). Invertebrate Reproduction \& Development, 61(2), 119-127.

Kerstitch, A., \& Bertsch, H. (2007). Sea of Cortez Marine Invertebrates (2nd Ed.). Monterey, California: Sea Challengers.

Lavoie, M.E. (1956). How Sea Stars Open Bivalves. Biological Bulletin, 111, 114-122.
Lawrence, J.M. (1987). A Functional Biology of Echinoderms. Baltimore, Maryland: Johns Hopkins University Press.

Lawrence, J.M. (2013). Starfish: biology and ecology of the Asteroidea. Baltimore, USA: Johns Hopkins University Press.

Lawrence, J.M., Keesing, J.K., \& Irvine, T.R. (2010). Population characteristics and biology of two populations of Archaster angulatus (Echinodermata: Asteroidea) in different habitats off the central-western Australian coast. Journal of the Marine Biological Association of the United Kingdom, 91, 1577-1585.

López-Luján, L., Chávez-Valderas, X., Zúñiga-Arelllano, B., Aguirre-Molina, A., \& Valentín-Maldonado, N. (2012). Un portal al inframundo: Ofrendas de animales sepultadas al pie del Templo Mayor de Tenochtitlan. Estudios de la Cultura Náhuatl, 44, 9-40.

Luna-Salguero, B.M., \& Reyes-Bonilla, H. (2010). Estructura comunitaria y trófica de las estrellas de mar (Echinodermata: Asteroidea) en arrecifes rocosos de Loreto, Golfo de California, México. Hidrobiológica, 20(2), 127-134.

Mah, C.L., \& Blake, D.B. (2012). Global diversity and phylogeny of the Asteroidea (Echinodermata). PloS one, 7(4), e35644.

Maheswaran, M.L., Narendran, R., Yosuva, M., \& Gunalan, B. (2015). Occurrence of abnormal starfish from Olaikuda in Rameswaran Islands, south east coast of India. International Journal of Fisheries and Aquatic Studies, 3(1), 415-418.

Manzur, T., Barahona, M., \& Navarrete, S.A. (2010). Ontogenetic changes in habitat use and diet of the sea-star Heliaster helianthus on the coast of central Chile. Journal of the Marine Biological Association of the United Kingdom, 90(3), 537-546.

Marsh, A.G., Watts, S.A., Chen, C.P., \& McClintock, J.B. (1986). The effect of high salinity on development, mortality and ray number of Echinaster spinulosus (Echinodermata: Asteroidea) at different developmental stages. Comparative Biochemistry \& Physiology, 83(2), 229-232.

Martín-Cao-Romero, C., Solís-Marín, F.A., CaballeroOchoa, A.A., Hernández-Díaz, Y.Q., Luján, L.L., \& Zúñiga-Arellano, B. (2017). New echinoderm remains in the buried offerings of the Templo Mayor of Tenochtitlan, Mexico City. Revista de Biología Tropical, 65(1-1), S168-S179.

Menge, B.A., \& Sanford, E. (2013). Ecological role of sea stars from populations to meta-ecosystems. In J.M. Lawrence (Ed.), Starfish: Biology and Ecology of the Asteroidea (pp. 67-80). Baltimore, USA: Johns Hopkins University Press. 
Metaxas, A. (2013). Larval ecology, settlement, and recruitment of asteroids. In J.M. Lawrence (Ed.), Starfish: Biology and Ecology of the Asteroidea (pp. 59-66). Baltimore, USA: Johns Hopkins University Press.

Migita, M., Mizukamib, E., \& Gunji, Y.P. (2005). Flexibility in starfish behavior by multi-layered mechanism of self-organization. BioSystems, 82, 107-115.

Moore, H.B. (1974). Irregularities in the test of regular sea urchins. Bulletin of Marine Science, 24, 545-567.

Moore, P.A., \& Lepper, D.M.E. (1997). Role of chemical signals in the orientation behavior of the sea star Asterias forbesi. Biological Bulletin, 192, 410-417.

O’Hara, T., \& Byrne, M. (2017). Australian echinoderms: biology, ecology and evolution. Clayton, Australia: CSIRO publishing.

Prabhu, K., \& Bragadeeswaran, S. (2012). Occurrence of abnormal starfish Astropecten indicus (Doderlein, 1888) (Echinodermata: Astroidea) along Southeast coast of India. Biotemas, 25(4), 293-296.

Ramsay, K., Bergmann, M., Veale, L.O., Richardson, C.A., Kaiser, M.J., Vize, S.J., \& Feist, S.W. (2001). Damage, autotomy and arm regeneration in starfish caught by towed demersal fishing gears. Marine Biology, $138(3), 527-536$

Reyes-Bonilla, H., González-Azcárraga, A., \& RojasSierra, A. (2005). Estructura de las asociaciones de las estrellas de mar (Asteroidea) en arrecifes rocosos del Golfo de California, México. Revista de Biología Tropical, 53, 233-244.

Reyes-Bonilla, H., Vázquez-Arce, D., González-Cuéllar, O.T., Herrero-Pérezrul, M.D., \& Weaver, A.H. (2016). Mass aggregation of the cushion starfish Pentaceraster cumingi in the southern Gulf of California. Marine Biodiversity, 48, 949-950.

Ríos-Jara, E., Galván-Villa, C.M., Rodríguez-Zaragoza, F.A., López-Uriarte, E., Bastida-Izaguirre, D., \& Solís-Marín, F.A. (2013). Los equinodermos (Echinodermata) de bahía Chamela, Jalisco, México. Revista Mexicana de Biodiversidad, 84, 263-279.

Santos, R., Gorb, S., Jamar, V., \& Flammang, P. (2005). Adhesion of echinoderm tube feet to rough surfaces. Journal of Experimental Biology, 208, 2555-2567.
Sebens, K.P. (1987). The ecology of indeterminate growth in animals. Annual Review of Ecology and Systematics, 18, 371-407.

Shanker, S., \& Vijayanand, P. (2014). Abnormal starfish, Pentaceraster regulus from Thondi, east coast of India. Cell and Developmental Biology, 3, 135.

Sloan, N.A., \& Aldridge, T.H. (1981). Observations on an aggregation of the starfish Asterias Rubens L. in Morecambe Bay, Lancashire, England. Journal of Natural History, 15(3), 407-418.

Solís-Marín, F.A., Laguarda-Figueras, A., Estrada Rodríguez, P., Honey Escandón, M.B.I., Martín CaoRomero, C., \& Durán González, A. (2014). Los asteroideos (Echinodermata: Asteroidea) del Golfo de California. México: SEMARNAT-INECC.

Stephenson, D.G. (1967). Pentameral symmetry in echinoderms. Nature, 216, 994.

Thomas, L.A., \& Hermans, C.O. (1985). Adhesive interactions between the tube feet of a starfish, Leptasterias hexactis, and substrata. Biological Bulletin, 169, 675-688.

Watts, S.A., Scheibling, R.E., Marsh, A.G., \& McClintock, J.B. (1982). Effect of temperature and salinity on larval development of sibling species of Echinaster (Echinodermata: Asteroidea) and their hybrids. Biological Bulletin, 163, 348-354.

Watts, S.A., Scheibling, R.E., Marsh, A.G., \& McClintock, J.B. (1983). Induction of aberrant ray numbers in Echinaster sp. (Echinodermata: Asteroidea) by high salinity. Florida Scientist, 46(2), 125-128.

Wu, L., Ji, C., Wang, S., \& Lv, J. (2012). The advantages of the pentameral symmetry of the starfish. arXiv, 1202.2219 .

Yousra, B.K., Sugni, M., Ferrario, C., Bonasoro, F., Oliveri, P., Martinez, P., \& Candia-Carnevali, M.D. (2018). Regeneration in Stellate Echinoderms: Crinoidea, Asteroidea and Ophiuroidea. In M. Klock, \& J. Kubiak (Eds.), Marine Organisms as Model Systems in Biology and Medicine. Results and Problems in Cell Differentiation (pp. 285-320). Berlín, Germany: Springer. 